\title{
Стан мікробного пейзажу в сучасній клініці кардіохірургії
}

\author{
Саламаніна А. О., Борисенко К. Ю., Ванда Т. М., Канавець Т. П. \\ ДУ «Науково-практичний медичний чентр дитячої кардіології та кардіохірургії МОЗ України» (Київ)
}

\begin{abstract}
В сучасній клініці важливою складовою є дослідження стану мікробного пейзажу, яке дає можливість призначити антимікробні препарати ще до отримання даних про ймовірного збудника інфекційного ускладнення та його чутливість до антибіотиків. Дослідження стану мікробного пейзажу може бути використане в практичній медицині для прогнозування ризику розвитку інфекційних ускладнень у пацієнтів із патологією серця, госпіталізованих для оперативного втручання в кардіохірургічну установу, для своєчасного, адекватного та цільового вибору антибіотика, а отже, для підвищення ефективності лікування та максимального скорочення терміну перебування хворого в умовах стаціонару.

Мікробіологічному моніторингу підлягали 192 пацієнти, госпіталізовані протягом 2016 року, які перебували у відділенні реанімації та інтенсивної терапії та тривало отримували антибактеріальні препарати; пацієнти, переведені з інших стаціонарів; пацієнти першого року життя, а також пацієнти, у яких виявлені гострі та хронічні вогнища інфекції та супутні захворювання.

За досліджуваний період виділено 519 ізолятів з 354 проб. Аналізу підлягали 249 культур умовно-патогенних мікроорганізмів, що виділялись із клінічного матеріалу найчастіше. Аналіз вказує на зростаючу роль коагулазонегативних стафілококів, зокрема Staphylococcus haemolyticus - 77 (31\%) та Klebsiella pneumoniae - 54 $(21,7 \%)$.

Дані, які надають інформацію про зміну мікрофлори в лікувальному закладі та наявність госпітальних штамів, сприяють своєчасному проведенню санітарно-протиепідемічних заходів з метою профілактики внутрішньолікарняних інфекцій.
\end{abstract}

Ключові слова: мікробний пейзаж, антибіотикотерапія, облігатна мікрофлора, дезінфектанти.

Стан мікробного пейзажу зумовлений сукупністю складних процесів міжвидових взаємовідносин, що протікають під дією безлічі агресивних факторів (фізичних і хімічних методів дезінфекції, антибіотиків), що є невід'ємною частиною роботи будь-якого стаціонару, в т.ч. кардіохірургічного. Бактерії, що піддаються селективному тиску факторів зовнішнього середовища, набувають нових властивостей - стійкості до зовнішніх впливів, підвищення вірулентності, резистентності до антимікробних препаратів та стійкості до дії дезінфектантів [1,2].

Зауважимо, що для різних органів і систем організму людини характерна та чи інша нормальна (облігатна) мікрофлора. Така асоціація певних видів мікроорганізмів виконує бар'єрну функцію щодо потрапляння до макроорганізму умовно-патогенної мікрофлори. Склад мікробних асоціацій багато в чому визначається станом організму в цілому i, у свою чергу, чинить імуномоделюючий вплив на організм господаря. Порушення нормальної мікрофлори організму (так званий дисбіоз) у ряді випадків $є$ підгрунтям для розвитку вторинних патологічних станів. У зв'язку із широким та часто безпідставним застосуванням антибіотиків проблема мікробного дисбалансу набула особливо великого значення. При знищенні нормальної мікрофлори людини, чутливої до певного препарату, створюються пріоритетні селекційні умови для колонізації та інтенсивного розмноження в організмі резистентних штамів. У результаті на фоні неефективної антибіотикотерапії виникають інфекційні ускладнення, які за перебігом іноді важчі від основного захворювання. Прикладом важких, небезпечних для життя ускладнень, які виникають при порушенні нормальної мікрофлори людини, є псевдомембранозний ентероколіт і кандидоз різної локалізації [3-5].

Дослідження стану мікробного пейзажу може бути використане в практичній медицині для прогнозування ризику розвитку інфекційних ускладнень у пацієнтів із патологією серця, госпіталізованих для оперативного втручання в кардіохірургічну установу; для своєчасного адекватного цільового вибору антибіотика, а отже, для підвищення ефективності лікування та максимального скорочення терміну перебування хворого в умовах стаціонару.

Мета дослідження - визначити перелік антибактеріальних препаратів, до яких чутлива найбільша кількість досліджених ізолятів.

Матеріали та методи. Мікробіологічному моніторингу підлягали 192 пацієнти, госпіталізовані протягом 2016 року, які перебували у відділенні реанімації 
та інтенсивної терапії та тривалий час отримували антибактеріальні препарати, пацієнти, переведені з інших стаціонарів, пацієнти першого року життя, а також пацієнти, у яких виявлено гострі та хронічні вогнища інфекції та супутні захворювання.

Пріоритетним стало спостереження за динамікою зміни мікробного пейзажу в тих відділеннях, які мають високий ризик формування, циркуляції та епідемічного поширення резистентних штамів. До таких відділень належать відділення реанімації та інтенсивної терапії.

Відбір матеріалу для мікробіологічного дослідження проводився згідно 3 наказом № 535 «Об унификации микробиологических методов исследования, применяемых в клинико-диагностических лабораториях ЛПУ».

Для бактеріологічного дослідження крові використовували автоматичну систему BacT/Alert $3 D$ (bioMerieux, Франція). Кров відбирали у флакони промислового виробництва того ж виробника, які містять поживне середовище для культивування аеробних та анаеробних мікроорганізмів. Ідентифікацію та визначення чутливості гемокультур до антибіотиків проводили на бактеріологічному аналізаторі VITEK 2 СОМРАCT (bioMerieux, Франція).

Інший клінічний матеріал досліджували ручними методами згідно 3 наказом № 535 «Об унификации микробиологических методов исследования, применяемых в клинико-диагностических лаборато今े риях ЛПУ». Ідентифікацію отриманих ізолятів проводили на бактеріологічному аналізаторі VITEK 2 COMPACT (bioMerieux, Франція). Визначення чутливості до антибіотиків проводили диско-дифузійним методом, згідно з чинними НД (наказ № 167, CLSI) або на бактеріологічному аналізаторі VITEK 2 COMPACT (bioMerieux, Франція).

Для проведення досліджень використовували поживні середовища та реактиви виробника HiMedia (Iндія). Якщо виділений ізолят з аналогічною резистентністю зустрічався повторно в того самого пацієнта, то його до уваги не брали (рис. 1).

Результати та обговорення. При досліджені 354 проб переважна кількість умовно-патогенних мікроорганізмів була виділена з верхніх дихальних шляхів - 256
- Слиз із зіву

- Слиз із носу

- Катетер для санаціі ВДШ

๓ Кров

" Пүпочне кільце

= Ексудати

I 3 мия із бронхів

" Судинні катетери

" Вмділення з очей

In Ceya

" Післяопераційна рана
- Staphylococcushaemolyticus

= Klebsiella pneumoniae

= Staphylococcus aureus

- Acinetobacter baumannii

m Enterococcus taecalis

= Pseudomonas aeruginosa

Кількістьізолятів

Рис. 2. Умовно-патогенні мікроорганізми, що виділялися з клінічного матеріалу найчастіше

(72\%); із крові - $16(4,6 \%)$, з пупочного кільця -21 (6\%), з нижніх дихальних шляхів - 21 (6\%); судинні катетери - 18 (5\%), післяопераційні рани - $12(3,5 \%)$, решта $-10(2,9 \%)$.

Із зазначеного вище клінічного матеріалу виділено 519 ізолятів. На рис. 2 представлено структуру виділених умовно-патогенних мікроорганізмів.

За досліджуваний період виділено 519 ізолятів 3 354 проб. Аналізу підлягали 249 культур умовно-патогенних мікроорганізмів, що виділялись із клінічного матеріалу найчастіше. Аналіз вказує на зростаючу роль коагулазонегативних стафілококів, зокрема Staphylococcus haemolyticus - $77(31 \%)$ та Klebsiella pneumoniae $-54(21,7 \%)$. 


\section{Таблиця 1}

Чутливість виділених ізолятів до антибіотиків

\begin{tabular}{|c|c|c|}
\hline Культура & Кількість & Чутливість \\
\hline $\begin{array}{l}\text { Staphylococcus } \\
\text { haemolyticus }\end{array}$ & $\mathrm{n}=77$ & $\begin{array}{l}\text { Лінезолід (95\%) >Ванкоміцин } \\
\text { (95\%) >Тейкопланін (88\%) } \\
\text { >Кліндаміцин (75\%) >Амікацин } \\
\text { (64\%) }\end{array}$ \\
\hline $\begin{array}{l}\text { Klebsiella } \\
\text { pneumoniae }\end{array}$ & $n=54$ & $\begin{array}{l}\text { Колістин (89\%) >Фосфоміцин } \\
(81 \%)>\text { Іміпенем (76\%) >Ертапе- } \\
\text { нем }(75 \%)>\text { Меропенем (74\%) }\end{array}$ \\
\hline $\begin{array}{l}\text { Staphylococcus } \\
\text { aureus }\end{array}$ & $n=36$ & 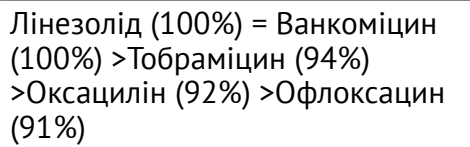 \\
\hline $\begin{array}{l}\text { Acinetobacter } \\
\text { baumannii }\end{array}$ & $\mathrm{n}=28$ & $\begin{array}{l}\text { Колістин (100\%) >Амікацин (71\%) } \\
>\text { Фосфоміцин (69\%) >Нетилміцин } \\
(63 \%)=\text { Офлоксацин }(63 \%)\end{array}$ \\
\hline $\begin{array}{l}\text { Enterococcus } \\
\text { faecalis }\end{array}$ & $n=28$ & 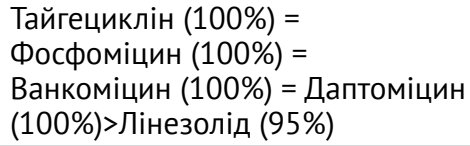 \\
\hline $\begin{array}{l}\text { Pseudomonas } \\
\text { aeruginosa }\end{array}$ & $n=26$ & $\begin{array}{l}\text { Колістин (100\%)>Фосфоміцин } \\
\text { (75\%) >Нетилміцин (59\%) } \\
\text { >Амікацин (54\%)>Ципрофлокса- } \\
\text { цин (54\%) }\end{array}$ \\
\hline
\end{tabular}

Було проведено аналіз чутливості виділених ізолятів до антибіотиків та виявлено п'ять антибактеріальних препаратів, до яких збережена чутливість у найбільшої кількості ізолятів (табл. 1).

\section{Висновки}

1. Виявлено провідну роль грампозитивних мікроорганізмів, серед яких переважне значення в етіології мають Staphylococcus haemolyticus - 77 (31\%) та Klebsiella pneumoniae - 54 (21,7\%).

2. Мікробіологічний моніторинг забезпечує ефективну емпіричну антибіотикотерапію.
3. Аналіз стану мікробного пейзажу у відділеннях реанімації та інтенсивної терапії дозволяє розробити алгоритми раціональної антибіотикотерапії конкретних нозологічних груп захворювань.

4. Виявлено $100 \%$-ву чутливість Acinetobacter baumannii до колістину та $37 \%$ резистентність до офлоксацину та нетилміцину.

5. Чутливість Pseudomonas aeruginosa до колістину становить $100 \%$, резистентність до ципрофлоксацину $-46 \%$.

6. Дані, які надають інформацію про зміну мікрофлори в лікувальному закладі та наявність госпітальних штамів, сприяють своєчасному проведенню санітарно-протиепідемічних заходів з метою профілактики внутрішньолікарняних інфекцій.

\section{Література}

1. Фадеева Т. В. Микробиологические аспекты инфицирования, реинфицирования и суперинфицирования при висцеральных гнойных процессах (в условиях многопрофильной клиники): Автореф. дис. ... д-ра биол. наук. Иркутск, 2007.

2. Яковлев С. В. Обоснование антибактериальной терапии нозокомиальных инфекций, вызванных полирезистентными микроорганизмами / С. В. Яковлев // Клиническая фармакология и терапия. - 2011. T. 20, № 2. - C. 24-34.

3. Changing epidemiology of bacteremia in infants aged 1 week to 3 months / T. L. Greenhaw [et al ] // Pediatrics. 2012. - Vol. 129 (3). - P. 590-6.

4. Gelot S. Intra-abdominal Infections in Adults / S. Gelot, E. Nakhla // US Pharm. -2016. - Vol. 41 (4). - P. 5-12.

5. Golan Y. Empiric therapy for hospital-acquired, Gram negative complicated intra-abdominalin fectionand complicated urina rytractin fections: a systematic literaturere view of current and emerging treatment options / Y. Golan // BMC Infectious Diseases. - 2015. Vol. 15. - P. 313.

\title{
Microbial Landscape In Current Clinical Cardiac Surgery
}

\author{
Salamanina A.O., Borysenko K. Yu., Vanda T. M., Kanavets T. P. \\ State Institution “Scientific and Practical Medical Centre for Children's Cardiology and Cardiac Surgery \\ of Ministry of Health of Ukraine" (Kyiv)
}

Currently in clinics, the study of microbial landscape is an important component allowing antimicrobials to be prescribed even before obtaining data on a possible agent causing infectious complication and its sensitivity to antibiotics. Study of microbial landscape can be used in medical practice in order to forecast the risk of infectious complications in patients with heart pathology admitted for surgical intervention at a cardiac surgery institution for timely, adequate and specific selection of an antibiotic, and thus to improve efficacy of treatment and reduce the patient's stay in a hospital as much as possible.

Microbial monitoring included 192 patients hospitalised during 2016 who were in the intensive care unit and received antibacterial agents for a long time, patients transferred from other hospitals, patients of $\leq 1$ year of age, as well as patients in whom acute and chronic infectious foci and concomitant diseases are detected.

During the study, 519 isolates were obtained from 354 samples. The analysis included 249 cultures of specified microorganisms, isolated from clinical material most commonly. The analysis shows the increasing role of coagulase-negative staphylococci, especially Staphylococcus haemolyticus (77 (31\%)) and Klebsiella pneumoniae (54 (21.7\%)). 
Data providing information on a change in microbiota at a hospital and presence of hospital strains contribute to timely performance of sanitary and antiepidemic measures in order to prevent intrahospital infections.

Key words: microbial landscape, antibiotic therapy, obligate microbiota, disinfectants.

\title{
Состояние микробного пейзажа в современной клинике кардиохирургии
}

\author{
Саламанина А. А., Борисенко Е. Ю., Ванда Т. Н., Канавец Т. П.
}

ГУ «Научно-практический медицинский центр детской кардиологии и кардиохирургии МОЗ Украины» (Киев)

В современной клинике исследование состояния микробного пейзажа дает возможность назначить антимикробные препараты до получения данных о возможных возбудителях инфекционных осложнений и чувствительности к антибиотикам. Исследование состояния микробного пейзажа может быть использовано в практической медицине для прогнозирования риска развития инфекционных осложнений у пациентов с патологией сердца, госпитализированных для оперативного вмешательства в кардиохирургических клиниках, для повышения эффективности лечения и максимального сокращения срока пребывания пациента в условиях стационара.

Обследованы 192 пациента, госпитализированные в течение 2016 года, которые находились в отделении реанимации и интенсивной терапии и длительное время получали антибактериальные препараты; пациенты, переведенные из других стационаров; пациенты первого года жизни, а также пациенты, у которых обнаружены острые и хронические очаги инфекции и сопутствующие заболевания.

За исследованный период выделено 519 изолятов из 354 проб. Анализу подвергались 249 культур условнопатогенных микроорганизмов, которые выделяли из клинического материала чаще всего. Анализ указывает на возрастающую роль коагулазонегативных стафилококков, а именно Staphylococcus haemolyticus - 77 (31\%) и Klebsiella pneumoniae - $54(21,7 \%)$.

Данные, содержащие информацию о смене микрофлоры в лечебном учреждении и наличии госпитальных штаммов, способствуют своевременному проведению санитарно-противоэпидемических мероприятий с целью профилактики внутрибольничных инфекций.

Ключевые слова: микробный пейзаж, антибиотикотерапия, облигатная микрофлора, дезинфектанты. 